\title{
Sweet's syndrome: One case of azathioprine-induced acute febrile neutrophilic dermatosis
}

\section{Síndrome de Sweet: un caso de dermatosis neutrofílica febril inducida por azatioprina}

\author{
Sónia Santos ${ }^{1 *}$, Katarina Kieselová2 ${ }^{2}$ António Antunes ${ }^{1}$, and Martinha Henrique ${ }^{2}$ \\ ${ }^{1}$ Internal Medicine Department; ${ }^{2}$ Dermatology Department. Centro Hospitalar de Leiria, Leiria, Portugal
}

\begin{abstract}
Sweet's syndrome (Acute febrile neutrophilic dermatosis) is a rare dermatosis that may be classified in three different groups: classical (or idiopathic), malignancy-associated or drug induced. The drug-induced disease most commonly occurs in patients who have been treated with granulocyte-colony stimulating factor, although other medications may also be associated. Sweet's syndrome is characterized by tender erythematous skin lesions (papules, nodules, plaques) together with fever, neutrophilia and a diffuse infiltrate consisting predominantly of mature neutrophils that are typically located in the upper dermis. We report a case of a 57-year-old male that initiated azathioprine two weeks before presenting scattered skin lesions associated with fever. The diagnosis of Sweet's syndrome was made. The corticoid dose was increased and azathioprine was discontinued. The patient improved within a week and did not have any relapse.
\end{abstract}

Key words: Azathioprine. Drug reaction. Febrile neutrophilic dermatosis. Sweet's syndrome.

\section{Resumen}

El síndrome de Sweet (dermatosis neutrofilica febril) es una dermatosis rara que puede presentarse de tres formas distintas: típica (o idiopática), relacionada con neoplasias e inducida por fármacos. El factor estimulador de colonias de granulocitos es el fármaco referido con más frecuencia, pero otros fármacos también pueden ser factores. Esta enfermedad aparece en la forma de lesiones cutáneas (pápulas, nódulos y placas dolorosos) acompañadas por fiebre, neutrofilia y un denso infiltrado de neutrófilos maduros, más abundante en la capa superior de la dermis. En este artículo se describe el caso de un hombre de 57 años que inició azatioprina dos semanas antes de la aparición de lesiones cutáneas dispersas y fiebre. Se estableció el diagnóstico de síndrome de Sweet. Se incrementó la dosis del corticoide y se suspendió la azatioprina. El paciente experimentó mejoría en el espacio de una semana y hasta la fecha no ha sufrido ninguna recaída.

Palabras clave: Azatioprina. Reacción a fármacos. Dermatosis neutrofilica febril. Síndrome de Sweet.

\section{Introduction}

Sweet's syndrome or Gomm-Button disease was originally described in 1964 as an acute febrile neutrophilic dermatosis, ${ }^{1}$ characterized by abrupt onset of fever, neutrophilia, painful edematous erythematous skin lesions (papules, nodules, plaques) and typical histopathological finding that include a diffuse infiltrate consisting predominantly of mature neutrophils, typically located in the upper dermis without vasculitis.
Correspondence:

*Sónia Santos

E-mail: soniacmsantos.mail@gmail.com
Date of reception: 29-05-2020

Date of acceptance: 18-02-2021

DOI: 10.24875/MCUT.20000045
Disponible en internet: 06-10-2021 Med Cutan Iber Lat Am. 2021;49(Suppl 1):26-29 www.MedicinaCutanealLA.com 0210-5187/C 2021 Colegio Ibero Latinoamericano de Dermatología A.C. (CILAD). Publicado por Permanyer. Este es un artículo open access bajo la licencia CC BY-NC-ND (http://creativecommons.org/licenses/by-nc-nd/4.0/). 
Acute febrile neutrophilic dermatosis can present in several clinical settings: classical (or idiopathic), malignancy associated, and drug-induced. ${ }^{1}$

A considerable number of drugs has been implicated as potential causes of this condition, such as: retinoic acid, trimethoprim-sulfamethoxazole, radiocontrast, dipyrone, hydralazine, furosemide, lithium, minocycline, quinolones, carbamazepine, contraceptives, diclofenac and diazepam. The most frequently implicated drug is granulocyte-colony stimulating factor. However, several other medications less often have been observed to promote the development of acute febrile neutrophilic dermatosis. ${ }^{1}$

A skin lesion biopsy for routine histopathologic evaluation is a useful procedure to confirm a clinically suspected diagnosis of acute febrile neutrophilic dermatosis. Pathologic features include a diffuse inflammatory infiltrate of neutrophils in the dermis, subcutaneous fat, or both, without leukocytoclastic vasculitis. ${ }^{1}$

The most consistent laboratory abnormalities in patients with acute febrile neutrophilic dermatosis are peripheral leukocytosis with neutrophilia and an elevated erythrocyte sedimentation rate. ${ }^{1}$

Differential diagnosis is made mainly with the following: erythema multiform, erythema nodosum, drug eruptions and leukocytoclastic vasculitis. ${ }^{2}$ Culture of lesional tissue for bacteria, fungi, and mycobacteria should be considered in order to rule out infection since the histologic pathologic changes associated with Acute febrile neutrophilic dermatosis are similar to those observed in an abscess or cellulitis. ${ }^{1}$

Systemic corticosteroids are the first line therapeutic for this condition, usually a dose of $1 \mathrm{mg} / \mathrm{kg} /$ day of prednisone. Alternatives are potassium iodide and colchicine. ${ }^{1}$

The eruption typically resolves spontaneously and subsequent resolution of the syndrome typically follows discontinuation of the associated medication in patients with drug-induced Acute febrile neutrophilic dermatosis but it recurs in approximately $30 \%$ of cases. ${ }^{3}$

Skin lesions may become secondarily infected and antimicrobial therapy may be necessary.

\section{Clinical case}

A 57-year-old male with autoimmune hepatitis sought emergency department complaining of productive cough, high fever $\left(39^{\circ} \mathrm{C}\right)$, dyspnea, arthralgia, headache and myalgia. The patient also complained to have a progressive tender erythema mainly in the limbs. He was chronically medicated with prednisolone $10 \mathrm{mg}$ and two weeks before had initiated

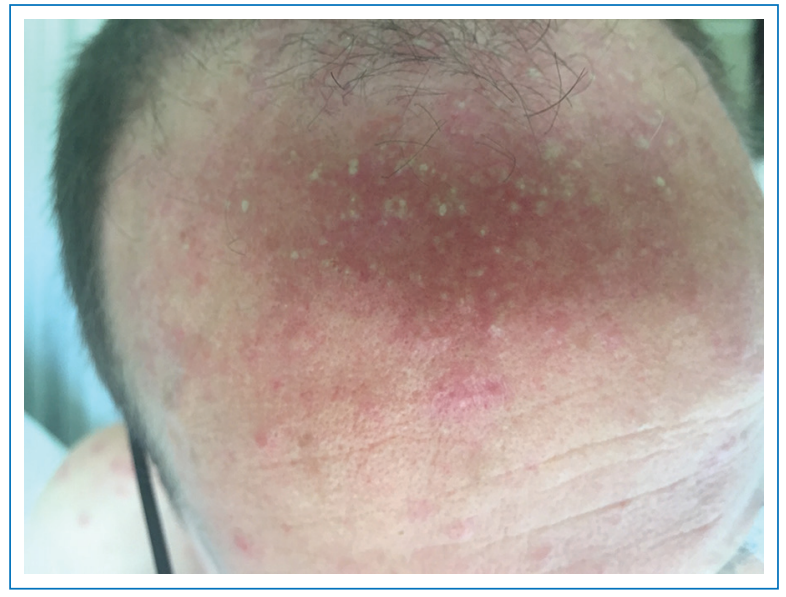

Figure 1. Forehead lesions with pustules.

therapeutic with azathioprine $50 \mathrm{mg} / \mathrm{day}$ due to autoimmune hepatitis.

On physical examination, the patient was febrile $\left(38,4^{\circ} \mathrm{C}\right)$; blood pressure was $128 / 65 \mathrm{mmHg}$, heart rate $100 \mathrm{bpm}$. He presented with a nonpruritic, painfull erythema on the knees, hands, forehead and back. The remainder of physical examination was normal.

Routine laboratory tests revealed leukocytosis $(145000 / \mu \mathrm{L})$ with neutrophilia $(87,9 \%)$, sedimentation rate $(30 \mathrm{~mm} / \mathrm{h})$, C-reactive protein elevated $(173 \mathrm{mg} / \mathrm{L})$, aspartate aminotransferase and alanine aminotransferase also elevated (116 U/L and $261 \mathrm{U} / \mathrm{L}$ respectively). There were no signs of renal dysfunction. His thiopurine methyltransferase activity was not measured.

Chest radiography showed a hilar bilateral infiltrate. The abdominal ultrasonography was normal. Blood and urine cultures were collected as urine antigens to Legionella and Streptococcus. All of them were negative.

Empirical antibiotic treatment with amoxicillin plus clavulanate and doxycycline was initiated. Despite antibiotic therapy inflammatory parameters maintained high.

During the hospital stay the erythema evolved to scattered tender inflammatory papules and plaques with pseudovesicles in the forehead (Fig. 1), back of the hands (Fig. 2), knees (and upper back (Fig. 3). Additionally, pustules on an erythematous base on the frontoparietal region were observed. The patient maintained fever accompanied by headache, myalgia and arthralgia. Acute febrile neutrophilic dermatosis induced by azathioprine was a diagnostic hypothesis so azathioprine was discontinued and the dose of prednisolone was increased to $1 \mathrm{mg} / \mathrm{kg} /$ day (60 mg/day). Two cutaneous biopsies were made, 


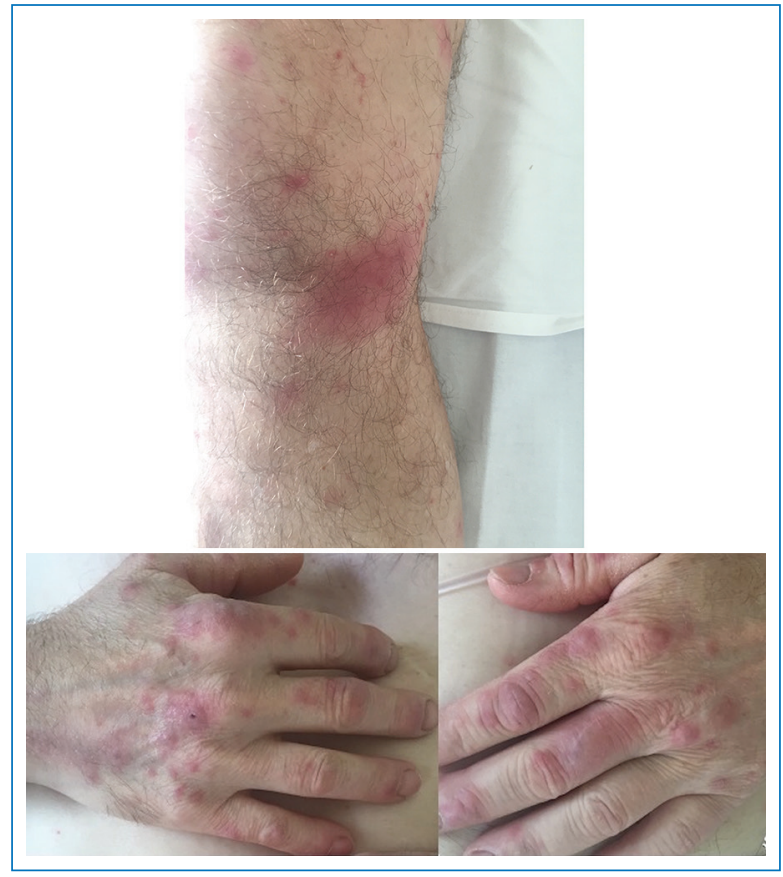

Figure 2. Erythematous papules and plaques with pseudovesicles on the back of the hands.

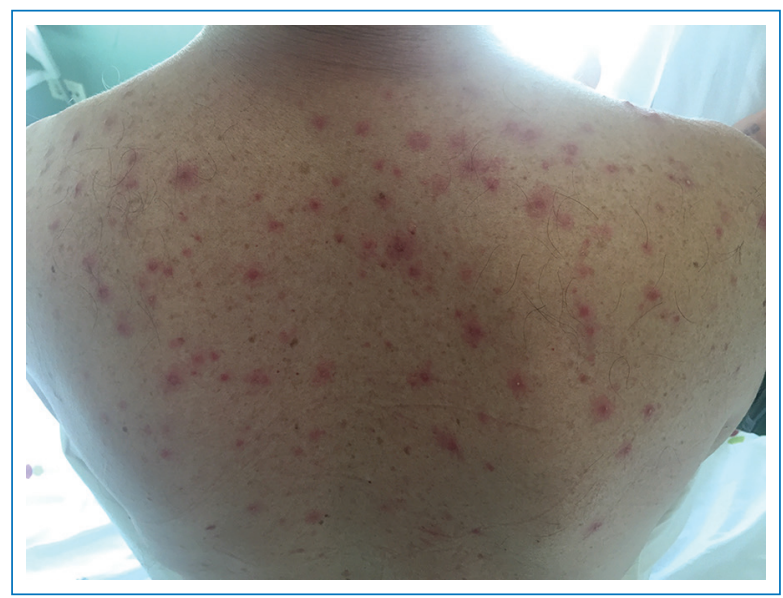

Figure 3. Erythematous papules and papulo-vesicles on the back.

one of the back of the hand - an erythematous plaque and another one of the back - lesion with pustule. Histology demonstrated polymorphonuclear cells and some lymphocytes compatible with Sweet's Syndrome. No evidence of vasculitis was observed. (Fig. 4)

The suspension of azathioprine and the treatment with corticosteroids resulted in notable improvement of symptoms within 48 hours.

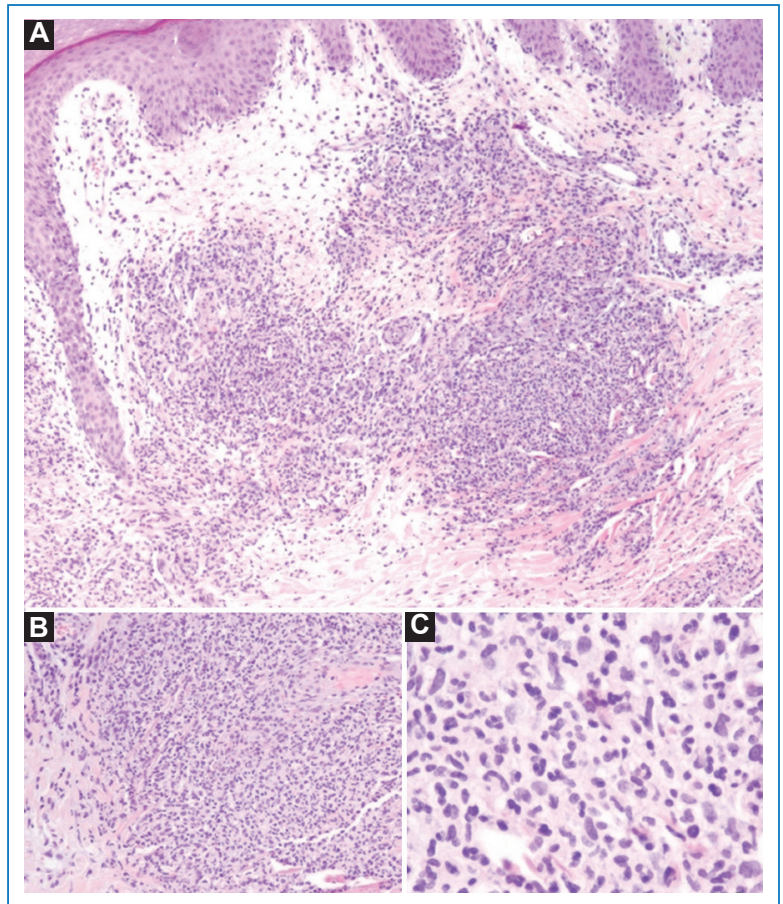

Figure 4. Histologic appearance of Sweet syndrome eruption. A: magnification 40x - intersticial and perivascular inflammatory infiltrate rich in polymorphonuclear cells. B: magnification 100x. C: magnification 400x showing polymorphonuclear cells.

The patient was discharged within a week and did not have any relapse till date.

\section{Discussion}

In 1986 the first patient with drug-induced Sweet's syndrome was reported ${ }^{4}$. In 1996, criteria for drug-induced Sweet's syndrome were established ${ }^{5,6,7}$ : i) Abrupt onset of painful erythematous plaques or nodules; ii) Histopathologic evidence of a dense neutrophilic infiltrate without evidence of leukocytoclastic vasculitis; iii) Temperature $>38^{\circ} \mathrm{C}$; iv) Temporal relationship between drug ingestion and onset of symptoms with drug rechallenge, and; v) Temporally-related resolution of lesions after drug withdrawal or treatment with systemic corticosteroids. All five criteria are required for the diagnosis of drug-induced Sweet's syndrome. ${ }^{1}$

Although acute febrile neutrophilic dermatosis itself is relatively rare, there has been an increasing incidence of the drug-induced subtype, most often in association with use of granulocyte colony-stimulating factor ${ }^{6}$. There also have been reported associations with a growing number of medications that include 
antibiotics, antiepileptic drugs, furosemide, hydralazine, all-trans retinoic acid, antivirals, cancer biotherapies, nonsteroidal anti-inflammatory and psychotropic drugs, oral contraceptives and propylthiouracil. ${ }^{3}$

Azathioprine is a purine analog that inhibits both DNA and RNA synthesis, that is usually used to treat auto-immune diseases in cases of steroid dependence or unresponsiveness. Azathioprine is rarely recognized to be a cause of acute febrile neutrophilic dermatosis. The first convincing case of azathioprine induced acute febrile neutrophilic dermatosis was described by Burrows in 1995. Since then, some cases of Sweet's syndrome secondary to azathioprine therapy have been reported ${ }^{8}$ but it is uncommon.

In a 2013 literature review ${ }^{8}$, seventeen cases were identified, twelve $(71 \%)$ were male, with a mean age of 47.2 years old. The time of onset after starting azathioprine was 5-28 days (mean, 13.3). Most of these cases were initially misinterpreted to be sepsis or associated with an exacerbation of the underlying disease. The most commonly associated disease was Inflammatory Bowel Disease (76\%).The clinical features consisted of fever and the typical rash of Sweet's syndrome most commonly on the face and trunk.

Our patient accomplished all the five criteria to the diagnosis of drug-induced Sweet's syndrome.

\section{Conclusions}

It is important to know that the diagnosis is often missed or delayed because clinical features are misinterpreted as being either severe septicemia or an exacerbation of the underlying disease state being treated. Therefore, this condition should be kept in mind for the clinicians. The role of dermatologist is crucial for a differential diagnosis and treatment.

\section{Acknowledgments}

Pathological Anatomy Service of the Hospital Center of Leiria.

\section{Funding}

The authors declare that they do not have commercial or financial relationship with any sponsor, or direct professional relationship with it.

\section{Conflicts of interest}

The authors declare that they do not have any conflict of interest.

\section{Ethical disclosures}

Protection of human and animal subjects. The authors declare that no experiments were performed on humans or animals for this study.

Confidentiality of data. The authors declare that they have followed the protocols of their work center on the publication of patient data.

Right to privacy and informed consent. The authors have obtained the written informed consent of the patients or subjects mentioned in the article. The corresponding author is in possession of this document.

\section{References}

1. Cohen PR. Sweet's syndrome - a comprehensive review of an acute febrile neutrophilic dermatosis. Orphanet Journal of Rare Diseases 2007;2(1):34.

2. Timbó RPF, Santos AS, Meotti CD, Oliveira FF, Lira KEB, Silva NF, et al. Sweet's Syndrome - Case Report and Review of how to investigate and treat. Revista Sociedade Portuguesa de Dermatologia e Venereologia 2013;71(1):79-84.

3. Bradley LM, Higgins SP, Thomas MM, Rodney IJ, Halder RM. Sweet Syndrome Induced by Oral Acetaminophen-Codeine Following Repair of a Facial Fracture. Cutis 2017;100.

4. Su WPD, Liu HNH. Diagnostic criteria for Sweet's syndrome. Cutis 1986;37:167-74.

5. Walker DC, Cohen PR. Trimethoprim-sulfamethoxazole-associated acute febrile neutrophilic dermatosis: case report and review of drug-induced Sweet's syndrome. J Am Acad Dermatol 1996;34:918-23.

6. Nelson AC, Noe NH, McMahon CM, Gowda A, WU B, Ashchyan HJ, et al. Sweet syndrome in patients with and without malignancy: A retrospective analysis of 83 patients from a tertiary academic referral center. American Academy of Dermatology 2018;78(2):303-9.

7. Nofal A, Abdelmaksoud A, Amer H, Nofal E, Yosef A, Gharib K, et al. Sweet's syndrome: diagnostic criteria revisited. Journal of the German Society of Dermatology 2017;15(11):1081-8.

8. Choonhakarn C, Chaowattanapanit S. Azathioprine-induced Sweet's syndrome and published work review. Journal of Dermatology 2013;40:267-71. 